\footnotetext{
A Andragoške studije, issn 0354-54I 5, BRoj I, JUn 2020, str. 53-76

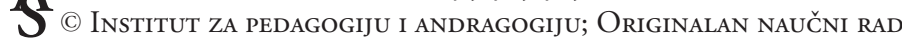

UDK 374.7:502.I3 I.I (438)(469)(497.4)

DOI: $10.5937 /$ ANDSTUD2001053K
}

Tadej Košmerl ${ }^{1}$

University of Ljubljana, Slovenia

Marta Gontarska ${ }^{2}$

University of Lower Silesia in Wroclaw, Poland

Yeonjoo $\mathrm{Kim}^{3}$

The University of British Columbia, Canada

Paula Cristina E. Guimarães ${ }^{4}$

University of Lisbon, Portugal

\title{
Helping to Postpone the Last Whimper: Adult Learning and Education for Sustainable Development in the National Energy and Climate Plans of Poland, Portugal and Slovenia
}

\author{
This is the way the world ends \\ Not with a bang but a whimper
}

(T. S. Elliot, The Hollow Men, 1925)

\begin{abstract}
The article compares discourses of the National Energy and Climate Plans (NECPs) of Poland, Portugal and Slovenia concerning the role of adult learning and education for sustainable development. NECPs are analysed through a theoretical proposal based on Escobar's (2005) and Krause's (2010) contributions, establishing three approaches to development and adult learning and education: a) a progress-oriented and

1 Tadej Košmerl, PhD student and teaching assistant, Department of Educational Sciences, Faculty of Arts, University of Ljubljana (tadej.kosmerl@ff.uni-lj.si).

${ }^{2}$ Marta Gontarska, PhD candidate, Faculty of Applied Studies, University of Lower Silesia in Wroclaw, Poland (marta.gontarska@student.dsw.edu.pl).

3 Yeonjoo Kim, PhD student, Department of Educational Studies, Faculty of Education, The University of British Columbia, Vancouver, Canada (yeonjook@mail.ubc.ca).

${ }^{4}$ Paula Cristina E. Guimarães, PhD, assistant professor, Institute of Education, University of Lisbon, Portugal (pguimaraes@ie.ulisboa.pt).
\end{abstract}


aware citizen approach; b) a global, critical and transformative approach; and c) an active global and local participatory approach. Main conclusions highlight a progress-oriented and aware citizen approach in the EU-initiated NECPs. Additionally, a top-down approach is evident in the policy documents, as well as an alignment with the liberal theory of development without a deeper reflection on local contexts, evidencing a marginal role of adult learning and education.

Keywords: education for sustainable development, adult learning and education, climate change, European Union

\section{Introduction}

Adult learning and education can be an important means of promoting sustainable ways of living and development. However, it may either be working just as a rhetorical slogan or it may shed a light on the relationships between adult learners' life and learning from the perspective of sustainable development. Within the legacy of liberal theory, a substantial body of scholarship has criticised the hegemonic understanding and liberal theory of development (Escobar, 2005). In this vein, the work of Krause (2010) elaborates the educative roles to raise awareness and to think of established ways of thinking, living and producing. Nowadays, sustainable development is a promising idea in both EU and Member States' policies. As such, the significance of the NECPs has risen to prominence. This article explores ways of thinking, living, and producing from the perspective of other (namely Marxist and post-structuralist) theories of development (Escobar, 2005) and the role of adult learning and education in achieving major changes in people's resulting global education and life skills perspectives (Krause, 2010).

To this end, based on document analysis and content analysis, this article aims to compare the discourse around national sustainable development policies in Poland, Portugal and Slovenia and the role given to adult learning and education in each country, addressing the following research question: How can we understand the policy discourse on adult learning and education in the NECPs of Poland, Portugal and Slovenia?

\section{Development, sustainable development and adult learning and education}

Several approaches to development may be found in theory. In the frame of modernisation discourses (Manzo, 1991), development has been a key idea in liberal theory (Escobar, 2005; Sachs, 1999) and the essential concept in plans for the 
reconstruction of countries devastated by World War II, as well as those that have become politically independent since then. Following the Bretton Woods agreements, development has been understood as economic growth fostered by states through organised and systematised planning. Programmes and projects implemented also included aims directed at increasing industrialisation and urbanisation; raising public participation in democratic societies and diffusing secular-rational forms of culture; increasing physical and social mobility through the implementation of transport; and fostering a social order for which individuals have to be equipped to function, for instance by means of education (Hart, 2001; Manzo, 1991). According to Krause (2010), this perspective of development may be related to education in terms of public relations and awarenessraising approaches preferred by governments to indoctrinate people concerning the benefits of development and to inform and encourage thinking on issues related to this topic. (Adult) education is given a relevant role in programmes based on a top-down approach to foster citizens' adaptation to existing rules and development guidelines.

After the social, economic and environmental crises of the 1960s and 1970s, this approach to development was strongly criticised. Manzo (1991) refers to 'a theoretical malaise' concerning development approaches, owing to 'rates of economic growth in many countries [...] unimpressive despite foreign aid, and, even in rapidly industrializing states [...] long term prospects of social equality and political democracy appeared poor' (p. 4). The Marxist approach (Escobar, 2005; Kay, 1998) has highlighted the economic disadvantage of countries from the South as a result of exploitation by Western countries (or the North) and of perspectives on development informed by state planning guidelines. In this line of reasoning, Krause (2010) points to the need of development education based on a global, critical and transformative approach. (Adult) education activities based on a bottom-up approach, according to Krause, are intended to raise awareness, to foster social and educational resistance to the hegemonic understanding of development when attempting to better understand the global interdependence between the North and the South, and to promote social and economic change.

Government intervention programmes and projects have shown the impasses created by the application of criteria from liberal development theories, such as the causal effect between economic growth and the increase of social injustice. Globalisation gives rise to new inequalities (social, cultural, political, educational, civic, environmental, etc.) (Sachs, 1999) between regions and countries. In many situations, Southern countries have uncritically adopted directions of development from the Northern developed countries and their economic experience. On the other hand, Southern experts, building on critical pedagogy theory, 
have stressed the understanding of development as a self-defined process of selfempowerment of local communities, together with a discourse against oppression, unequal power relations and the lack of self-confidence (Freire, 1968; Said, 1979; Giroux, 2001). The Southern perspective, according to Tandon (2008), brings a new understanding of development based on social and democratic factors, as well as the idea of eliminating imperialism: 'Imperialism is often a taboo word, usually avoided in polite intellectual discourse' (p.14). His view is also linked to the global perspective in education described by Andreotti and its trap of "promoting a new "civilising mission" as the slogan for a generation who take up the "burden" of saving/educating/civilizing the world' (Andreotti, 2014, p. 22). Like Tandon, Andreotti addresses the origins of assumptions and implications regarding development and global citizenship.

Among those criticizing the liberal theory of development (Escobar, 2005), several authors have raised new approaches, such as those referring to sustainable development. Some of these perspectives pointed at the need to make surgical changes in our societies concerning economic growth. The understanding of sustainable development adopted by the United Nations (UN), despite being considerably broad, follows this path (Sachs, 1999). Selby and Kagawa (2014, pp. 149-152) noted the fundamental problem with the concept of sustainable development, which still refers to economic growth. These authors discuss the vague definition that may be found in the Brundtland Commission's (1987) report, which assumes a clear link between sustainability and the ability to grow, which seems to be impossible given the planet's limited resources. Likewise, the framework of neoliberal growth and globalisation presented in the concept involving top-down decision-making mechanisms requires questioning of the whole idea of sustainable development education and values. To question power relations, to reveal the hidden agendas confirming the status quo, and to formulate suggestions to overcome the politically-driven agenda of sustainable development requires shedding light on new alternatives, as a result of the effort to 'ask questions and speak truth to power or capitalise on Trojan horses within the walls of mainstream thinking' (Selby \& Kagawa, 2014, p. 153).

Therefore, in recent writings, several authors have argued for the need to overcome the North-South perspective and to consider the social ethics of local and global issues (Krause, 2010); others, sustaining post-structuralist approaches, have stressed the importance of re-inventing life on planet earth, defending alternative forms of thinking, living and producing, like the buen vivir proposal (Escobar, 2005, 2012) and the critical thinking and ethical approach of liberation (Dussel, 2015). Other authors call for de-growth (Kallis, Demaria, \& D'Alisa, 2015; Latouche, 2012). Despite their differences, these approaches share a strong 
criticism of capitalism (as insisting on economic growth), which destroys existing natural resources and condemns life on Earth to extinction. Arguments have focused on the importance of politicizing discourses, above all concerning the unquestioned benefits brought on by technology and science. Likewise, the need for problematising globalisation and political (top-down) decision-making has been raised, with the future of humankind in mind. In present times, liberation through ethics based on critical approaches is central in this effort (Dussel, 2015); (adult) education is significant when stressing the interdependence of the spheres of political decision-making and intervention - by highlighting the connection between thinking globally and acting locally - and the emergence of a (new) political ecology based on a civilisation model that respects differences and the existing pluriverse of social and natural worlds that still may be found today in the world (Escobar, 2012). Within this frame, (adult) education has to be based on an actor-centred approach in the search of citizens as agents of social change as part of local and global communities of thinking and practice (Krause, 2010).

\section{The EU's narrow understanding of sustainable development}

In the last two decades, and especially since 2015, sustainable development has come to the forefront on policy agendas. Sustainable development as a term refers to two main references in supranational political documents, which should be mentioned when discussing the concept. The UN's comprehensive concept described by Brundtland Commission's (1987) report Our Common Future highlights the importance of ensuring the ability of future generations to meet their needs based on four main pillars: society, environment, culture and economy. As a discourse framed on an international level, the concept has been received differently on the national level, depending on the areas and topics prioritised by each country, meaning that the connections between pillars have not been as visible as expected (Sachs, 1999). Since the publication of the Brundtland report, a broader understanding of sustainable development has been presented in several policy documents, including the UN's (2015) Agenda 2030, which describes 17 Sustainable Development Goals (SDGs), which were launched as a new social contract for a new era, harmonizing three core elements: economic growth, social inclusion and environmental protection. The SDGs address the presence of actions on climate change, the sustainable use of resources, and the need to support marginalised groups to mitigate global inequalities. Still, the implementation process relies on national strategies and public policies as well as on stakeholders, governments, the private sector, civil society and others. These different 
actors are expected to contribute to the realisation of the SDGs, although multiple understandings of this concept can be observed, such as in Portugal (Schmidt \& Guerra, 2013). The SDGs are also followed by the European Union (EU), as they are 'fully consistent with EU values and principles' (European Union [EU], 2018 b, p. 2), although the EU has adopted a narrower understanding even when compared to the UN guidelines. For this purpose, the EU has been promoting different initiatives, including the first ten-year integrated NECPs developed between 2015 and 2020 by all the EU Member States (including the United Kingdom) in a process that, until further notice, will be repeated every decade to establish a 'reliable and transparent governance mechanism without any unnecessary administrative burden and with sufficient flexibility for the Member States' (EU, 2018a, p. 3).

The NECPs set out the national objectives of each EU Member State in five key areas (energy efficiency, renewables, greenhouse gas, interconnections, and research and innovation) and the corresponding policies and measures to successfully address these areas (European Commission [EC], 2019a; EU, 2018a). They represent the EU's commitment to contributing to the UN's 2015 Paris Agreement on Climate Change and the UN's development approach; in fact, the NECPs are designed to be 'consistent with, and contribute to, achieving the United Nations Sustainable Development Goals' (EU, 2018a). This commitment aims to keep the increase in global average temperature well below $2^{\circ} \mathrm{C}$ in comparison with the pre-industrial climate level (although the Paris Agreement does not define this pre-industrial/base climate level); it also includes meeting the EU's ultimate climate goal of making Europe the first continent to achieve netzero greenhouse gas emissions and carbon neutrality by 2050 and negative emission after that (EU, 2018a). In line with the Regulation on the Governance of the Energy Union and Climate Action, all EU Member States were required to submit their first NECPs by the end of 2019 (EC, 2019a; EU, 2018a). Each country will also have to issue a report every two years (the first on 15 March 2023) on their progress in the implementation of the NECPs (EU, 2018a).

The current NECPs are established for the 2021-2030 period (including an outlook on 2040 and 2050) and are directed at contributing towards the three key objectives of the EU's 2030 climate \& energy framework to be achieved by 2030 - to reduce greenhouse gas emissions by at least $40 \%$ in comparison to the 1990 s levels, to generate at least $32 \%$ of energy from renewable sources, and to make a 32.5\% improvement in energy efficiency from the 1990s levels, although Member States set their own national targets (EC, 2014, 2018). The EU (2018a) published a detailed template for countries to follow in the development of their NECPs. Although giving Member States some flexibility to accommodate their 
national contexts, some main categories have to be followed by all countries and should be included in each national NECP (EU, 2018a):

- $\quad$ an overview of the process of developing the NECP, including effective opportunities for citizens and stakeholders to participate in shaping the NECP,

- the description of the established national objectives, planned policies and measures, and barriers to achieving those objectives,

- the description of the current national situation concerning energy and climate,

- the assessment of the impacts of the planned policies and measures on the established objectives and competitiveness,

- an overview of the methodology and policy measures to achieve the required energy savings as established in a 2012 EU directive on energy efficiency.

The NECPs are a governance mechanism under the Energy Union, a framework/strategy established as one of the ten priorities of the Juncker Commission in 2015 (EC, 2020; EU, 2015) in order to establish a forward-looking climate change policy, to transform the EU's energy system and to make it more sustainable, secure and competitive (Bassot \& Hiller, 2019). Climate action and decarbonisation are the 'mutually-reinforcing' objectives of the EU's Energy Union, including other dimensions such as energy security and solidarity; an integrated European energy market; energy efficiency; and research, innovation and competitiveness (EU, 2015). The NECPs should contribute to those goals, while particularly focusing on the EU's commitments on the reduction of greenhouse gas emissions in line with the Paris Agreement (EC, 2020; EU, 2018a).

More recently, the NECPs have also been incorporated into The European Green Deal (introduced in December 2019 as the first of the six political priorities of the von der Leyen Commission), which reiterates the goal of making the EU climate neutral by 2050 and promises to strengthen the EU's effort in dealing with climate change and establishing a European Climate Law (EC, 2019b). Although the NECPs currently constitute the main EU climate governance mechanism that needs to be followed by all Member States (in order to receive all the financial benefits of the EU), many more policies and measures may be coming in the next few years, similarly highlighting the transformation of the energy system but also focusing more on mobility and food systems, on preserving and restoring ecosystems and biodiversity, and on adopting a zero pollution plan for air, water and soil (EC, 2019b). 


\section{(Sustainable) Development and adult learning and education:}

\section{A theoretical framework}

EU policy documents do not clearly refer to the role of adult learning and education. However, owing to the importance sustainable development has as a policy in peoples' lives, a link may be established between this concept and adult learning and education within a theoretical framework referring to development, as a broad concept, and education as an embracing idea. For the purpose of this article, following Escobar's (2005) and Krause's (2010) arguments, a theoretical proposal was built. This theoretical proposal is based on the theories of development (Escobar, 2005). Escobar stresses three theories of development, emphasizing several variables ${ }^{5}$. Krause's (2010, pp. 3-7) theoretical proposal takes into consideration the links to be established between (adult learning and) education and (sustainable) development, following several categories of analysis $^{6}$. These two contributions were combined, and the arguments presented below are aimed at offering an integrated proposal of analysis. This proposal is built on ideal-types; however, mixed forms may be found, hence each type does not exclude the others when an object of study is discussed. In this article, the variables used by both authors are combined. The outcome includes the following categories of analysis: understanding of sustainable development, role of adult learning and education, and learners' roles and forms of adult learning and education.

Concerning the understanding of sustainable development, the first approach to development in adult learning and education - the 'progress-oriented and aware citizen approach' - emphasises the role of adult learning and education as a tool for raising awareness of the benefits of development to promote a fairer

5 Escobar (2005, p. 21) identifies several variables such as epistemology, key concepts, object of study, relevant actors, questions of development, criteria for change, mechanisms of change, ethnography, critical attitude towards development and modernity.

${ }^{6}$ Krause (2010) identifies several categories such as thematic scope, goal, educative approach, pedagogic thought, target group and context. This author identifies four ideal-types of development education, although he argues that one of these ideal-types is illegitimate. About the non-recognized approach to development education, Krause says the following: 'DE as Public Relations for development aid (PR): DE denotes communication activities aiming at predefined outcomes in terms of public support for development cooperation efforts, e.g. pro-aid campaigns, the promotion of the positive results of development co-operation by aid agencies, fundraising of NGOs. Although some actors do call such kind of Public Relations work "Development Education", there is a consensus among the European community of DE stakeholders that PR should not be recognised as part of DE.' (Krause, 2010, p. 7) In fact, governments in many countries have implemented media campaigns and other information and sensibilization programmes and projects referring to (sustainable) development, being activities promoted not clearly related to adult learning and education. For this reason, in the typology built for the purpose of this article, Public Relations for development aid (PR) will not be included. 
society. Regarding the role of adult learning and education, adult learning and education activities are directed at informing people about development topics, based on main guidelines raised to follow the progress of societies and leading to economic growth. Learners' roles and forms of adult learning and education involve information on the adequate exploitation of natural resources for improving living conditions, namely the conditions known in Northern countries as the ones aimed at social and human development. Giving economic and social organisations the possibility of gaining maximum benefits from science and technology is a strong aim of this approach.

In the second approach to development in adult learning and educationthe 'global, critical and transformative approach' - the understanding of sustainable development is based on critical thinking about the local and global interdependence of sustainable development, human rights and ecological issues. Adult learning and education aims at transforming existing social relations, which are viewed as instruments to exploit local communities and countries that do not have the power to change (Freire, 1968; Giroux, 2001). Blurring the relationship between 'oppressors' and 'oppressed' is of utmost importance. To resist globalisation is an important trend to be followed; alternatives must be raised, and it is urgent to bring back power to communities. Therefore, learners' roles and forms of adult learning and education foster a radical transformation of existing economic and social relations. Owing to this purpose, individual responsibility is a serious concern in adult learning and education projects promoted by state departments and services and non-governmental organisations.

In the third approach - the 'active global and local participatory approach' - the understanding of sustainable development focuses on the promotion of knowledge through a wide range of projects and activities, involving large sectors of the population, in order for (adult) learners to foster political ecological guidelines, to have the power to affect changes in local environments and global arenas as well. Knowledge acquisition is valuable to develop social ethics, and local and global issues are part of several cosmovisions. Concerning the role of adult learning and education, the emphasis is on the promotion of knowledge that establishes a connection between expert information, respect for nature and local communities' cultural ethics, as well as the practice of freedom, as part of alternative modes of thinking, living and producing. Thinking globally, acting locally is a basis for empowering local communities in what relates to learners' roles and forms of adult learning and education in social and individual learning, stimulating respect for the diversity to be found in the world, starting with pluriversal knowledge and attitude. The production of new discourses and meanings directed at the emergence of new ways of thinking and new ways of thinking, living and producing is a central issue for all social actors. 
Table 1: Approaches to development and adult learning and education (Adapted from Escobar, 2005 and Krause, 2010)

\begin{tabular}{|c|c|c|c|}
\hline Categories & $\begin{array}{l}\text { Progress-oriented and } \\
\text { aware citizen approach }\end{array}$ & $\begin{array}{l}\text { Global, critical and } \\
\text { transformative approach }\end{array}$ & $\begin{array}{l}\text { Active global and local } \\
\text { participatory approach }\end{array}$ \\
\hline \multirow{5}{*}{$\begin{array}{l}\text { Understanding } \\
\text { of susstainable } \\
\text { development }\end{array}$} & \multirow{4}{*}{$\begin{array}{l}\text { To raise awareness of the } \\
\text { benefits of development } \\
\text { To promote a fairer society } \\
\text { within existing rules and } \\
\text { social and economic } \\
\text { structure } \\
\text { To foster a Western } \\
\text { understanding of } \\
\text { development to be adopted } \\
\text { by Southern countries }\end{array}$} & $\begin{array}{l}\text { To raise critical thinking } \\
\text { on local and global } \\
\text { interdependence between } \\
\text { the North and the South }\end{array}$ & $\begin{array}{l}\text { To develop knowledge through } \\
\text { a wide range of projects and } \\
\text { activities }\end{array}$ \\
\hline & & \multirow{2}{*}{$\begin{array}{l}\text { To foster the links } \\
\text { between human rights and } \\
\text { environmental issues }\end{array}$} & $\begin{array}{l}\text { To affect changes in local } \\
\text { environments and in global arenas }\end{array}$ \\
\hline & & & \\
\hline & & $\begin{array}{l}\text { To promote radical changes } \\
\text { in modes of production and } \\
\text { consumption }\end{array}$ & $\begin{array}{l}\text { emergence of new ways of } \\
\text { thinking and new ways of } \\
\text { thinking, living and producing }\end{array}$ \\
\hline & $\begin{array}{l}\text { To develop a top-down } \\
\text { approach }\end{array}$ & $\begin{array}{l}\text { To implement a bottom- } \\
\text { up approach blurring } \\
\text { dichotomous relationships } \\
\text { between oppressors and } \\
\text { oppressed }\end{array}$ & $\begin{array}{l}\text { To use a bottom-up approach to } \\
\text { reinforce local communities' roles }\end{array}$ \\
\hline \multirow{3}{*}{$\begin{array}{l}\text { Role of adult } \\
\text { learning and } \\
\text { education }\end{array}$} & \multirow{3}{*}{\begin{tabular}{|l|} 
To inform people of \\
development topics \\
To raise awareness of \\
development by fostering \\
progress of societies \\
through economic growth
\end{tabular}} & \multirow{3}{*}{$\begin{array}{l}\text { To transform existing } \\
\text { social relations based on } \\
\text { exploitation } \\
\text { To promote knowledge } \\
\text { and abilities to strengthen } \\
\text { adult learners and local } \\
\text { communities to create } \\
\text { change }\end{array}$} & $\begin{array}{l}\text { To establish a connection between } \\
\text { expert information, respect for } \\
\text { nature and local communities' } \\
\text { cultural ethics }\end{array}$ \\
\hline & & & $\begin{array}{l}\text { To use adult learning and } \\
\text { education as a tool within } \\
\text { practices of freedom and liberation }\end{array}$ \\
\hline & & & $\begin{array}{l}\text { To foster knowledge and abilities } \\
\text { related to alternative modes of } \\
\text { thinking, living and producing }\end{array}$ \\
\hline \multirow{3}{*}{$\begin{array}{l}\text { Learners' roles } \\
\text { and forms of } \\
\text { adult learning } \\
\text { and education }\end{array}$} & \multirow{3}{*}{$\begin{array}{l}\text { Informing people in } \\
\text { general on the adequate } \\
\text { exploitation of natural } \\
\text { resources for improving } \\
\text { living conditions } \\
\text { Raising awareness serves } \\
\text { the need of promoting } \\
\text { instrumental social and } \\
\text { human development } \\
\text { within capitalism; adult } \\
\text { learning and education } \\
\text { activities are in many } \\
\text { occasions promoted by } \\
\text { professionals and/or adult } \\
\text { educators and trainers } \\
\text { directed at fostering } \\
\text { specific programme aims } \\
\text { Promoting small changes } \\
\text { that do not challenge the } \\
\text { existing economic, political } \\
\text { and environmental order }\end{array}$} & \multirow{3}{*}{$\begin{array}{l}\text { Promoting a broad } \\
\text { understanding of the } \\
\text { complex relationships } \\
\text { between people, the state } \\
\text { and the market in the } \\
\text { era of global capitalism, } \\
\text { which hides the strong } \\
\text { links between all subjects } \\
\text { involved and the constraints } \\
\text { to force changes } \\
\text { Blurring the dichotomous } \\
\text { relationships between } \\
\text { oppressors and oppressed } \\
\text { Fostering radical } \\
\text { transformation of existing } \\
\text { economic and social } \\
\text { relations; adult educators } \\
\text { and other professionals } \\
\text { have to be engaged in social } \\
\text { transformation }\end{array}$} & $\begin{array}{l}\text { Empowering and emancipating } \\
\text { local communities is considered a } \\
\text { major aim } \\
\text { Involving a wide range of social } \\
\text { actors (individual or institutional), } \\
\text { state departments and services, } \\
\text { civil society organisations and } \\
\text { social movements; adult educators } \\
\text { are seen as activists fostering } \\
\text { new ways of thinking, living and } \\
\text { producing }\end{array}$ \\
\hline & & & $\begin{array}{l}\text { Valuing new knowledge created by } \\
\text { local communities and stimulating } \\
\text { respect for the diversity to be } \\
\text { found in the world, starting } \\
\text { by acknowledging pluriversal }\end{array}$ \\
\hline & & & $\begin{array}{l}\text { knowledge and abilities - major } \\
\text { changes in meaning given to ways } \\
\text { of thinking, living and producing } \\
\text { are fostered }\end{array}$ \\
\hline
\end{tabular}




\section{Methodology}

To gain a meaningful understanding of the role of adult learning and education for sustainable development in policy discourse, a document analysis was performed for this study, based on the method of qualitative inquiry (Denzin, 2018). As Bowen $(2003,2009)$ shows, document analysis can provide 'contextual richness' (Bowen, 2009, p. 36) to understand the socio-historical and politico-economic background of the topic. It consists of two main stages: selecting the documents to be analyzed and then analyzing the documents. In the first stage - selecting the documents - a selection of national documents, namely the NECPs of three countries (Poland, Portugal, and Slovenia) was made. ${ }^{7}$ For the comparative analysis, we took a closer look at how three EU Member States from different parts of Europe developed their NECPs. As the NECPs require coordination across all government departments (EC, 2019), it is expected that they will have an impact on education as well (EU, 2018a). By analysing their NECPs, we could determine how national governments currently see the role of (adult) learning and education in contributing to the UN's Paris Agreement targets to reduce greenhouse gas emissions, and we could identifiy the main similarities and differences between those perceptions, which were developed under the common influence of the EU.

The second stage - analyzing the documents - involves three sub-stages performend in an iterative manner: a) skimming, b) reading, and c) interpreting. Throughout this 'systemic procedure for reviewing and evaluating' (Bowen, 2009, p. 27), the work of Escobar (2005) and Krause (2010) allowed us to build the theoretical framework. Putting the research question at the centre of this process to make the substantial comparison, we followed four steps: a) descriptive juxtaposition, b) analytical juxtaposition, c) descriptive comparison, and d) analytical comparison (Egetenmeyer, 2012). Simultaneously, as researchers from Portugal, Poland, and Slovenia, respectively, we acknowledge our 'ethnocentric perspective[s]' (Mason, 2007, p. 183). However, given the collaborative process, which included a researcher originally from South Korea and currently living in Canada, the process of evaluating documents and writing allows for 'greater confidence in [the credibility] of the findings' (Bowen, 2009, p. 30). In the end, this study produces key findings within the three categories: 1) understanding of sustainable development, 2) the role of adult learning and education, and 3) learners and forms of adult learning and education.

\footnotetext{
7 The NECP discourses were analysed in the respective native language (Ministry of State Assets of the Republic of Poland, 2020a; The Government of Portugal, 2020a; The Government of the Republic of Slovenia, 2020a); their official English translations were used when paraphrasing or quoting from the documents (Ministry of state Assests of the Republic of Poland [Poland], 2020b; The Government of Portugal [Portugal], 2020b; The Government of the Republic of Slovenia [Slovenia], 2020b).
} 


\section{Data analysis}

\section{Perception of sustainable development}

Climate change and actions mitigating climate changes/the climate crisis are included in the Sustainable Development Goals (Goal 13), interlinked with various other goals related to biodiversity, consumption and wildlife preservation. The topic is even more alarming after the publication of the Intergovernmental Panel on Climate Change (IPCC, 2019) report entitled Global Warming of $1.5^{\circ} \mathrm{C}$. It is worth noting that sustainable energy is also among the separate goals in the Agenda (Goal 7). Despite the importance such policy documents may have for humankind, all analysed plans narrow down the UN's perspective on sustainable development, highlighting mostly the economic and environmental perspective. Decision-makers emphasise the role of technologies and business in mitigating the negative effects of climate change, giving society and citizens only a marginal role in the process. Still, we found no discussion and reflection based on the causes or consequences of climate change following a broader perspective. Plans do refer to climate change in the title, but most of what can be found in these documents suggests the attempt to solve the issues of decarbonisation and energetic sustainability.

This new energy model for carbon neutrality represents a unique opportunity for Portugal. In relation to the economic recovery which the country has achieved in recent years, the challenge of energy transition is seen as an opportunity which will allow the economy to be leveraged. The aim is to achieve sustainable development based on a democratic and fair model which promotes the advance of civilization and technology, the creation of jobs and prosperity, the creation of wealth and territorial cohesion while also preserving natural resources. The path to the decarbonisation of the economy is also an opportunity for economic growth. (Portugal, 2020b, p. 19)

Overestimating the role of technology and evidencing a lack of a holistic approach towards sustainability, including emissions (?) reduction and limited worldwide resources, the plans seem to be influenced by a market-oriented perspective. The lack of sensitivity to human rights and equal participation in sustainable development makes it even easier to understand the narrow perspective on sustainable development adopted by the EU and by the countries selected for this analysis. The Portuguese plan frequently refers to the Agenda 2030, stressing an advanced understanding when comparing to the EU's way of relating to this important topic. 
In terms of background, it is important to note that Portugal, in the context of Agenda 2030 for sustainable development, had already defined SDG 13 - Climate Action to be a priority target. The identification of SDG 13 as a priority target is directly related to Portugal's ambitions in terms of complying with SDG 7-Affordable and Clean Energy for all. In addition to the aforesaid targets, SDG 4-Quality Education, SDG 5-Gender Equality, SDG 9-Industry, Innovation and Infrastructure and SDG 10-Reduced Inequality were also identified as priorities. (Portugal, 2020b, p. 24)

And yet, the understanding of sustainable development presented in the document is still broad and vague when it comes to defining the process and much more supportive of technological and economic factors. The energy transition as the key goal to be achieved by 2040 is connected with social factors, although stressing the process towards a carbon-neutral society.

[...] the Government of the Republic of Slovenia adopted the Slovenian Development Strategy 2030 (Strategija razvoja Slovenije - SRS 2030), a framework document on national development that places quality of life for all at the forefront. The strategy incorporates globally agreed sustainable development goals as well as five strategic orientations and twelve interrelated development goals that lay down new long-term development foundations for Slovenia. (Slovenia, 2020b, p. 16)

The Slovenian document quotes sustainable development, but the understanding is focused on the economic and environmental dimension, whereas the social aspect is rather underrepresented in the narrative. The weakest link between global sustainable development and the plan is presented by the Polish one, including references to the role of specific sectors such as agriculture or fishery.

Reduction of the civilisation gap between Poland and highly developed economies and improvement of the quality of life of Polish people, as well as the fulfilment of the development aspirations of the present and future generations consistently with the sustainable development principle. (Poland, 2020b, p. 45)

\section{The role of adult learning and education}

The character of the NECPs is based on the European guidelines; these technical policy documents include goals, measurements and market-oriented criteria. Depending on each country's context, education could have an important role in reaching the goals and broadening citizens' understanding of climate change. 
However, the plans analysed here never show a strong connection to education, nor to adult education, even though adults are among the main target groups of the proposed activities. For instance, words such as education, training and learning are not much visible in the plans, which shows the marginal status of (adult) learning and education. The NECPs adequately reflect what was decided at the international level in the frame of EU energy policy as part of the fight against climate change, strongly focussing on the correct management of energy systems and tending to overlook some of the other ways that might also help reduce greenhouse gas emissions. For example, the Portuguese Plan proposes actions such as the ones listed below, but there is no subsequent mention of further education and learning guidelines:

\subsubsection{Promote capacity-building (education and training) to mitigate climate change, develop a low-carbon economy and improve air quality 8.3.4. Promote awareness and capacity-building (education and train- ing) actions for more sustainable production and consumption patterns (Portugal, 2020b, p. 72)}

The potential role of adult learning and education to strengthen awareness of climate change and to create a society based on sustainable development is absent. The plans only stress the strategic minimal presence related to market-oriented goals and the professionalisation of dedicated groups of adults, such as workers from different sectors, farmers or research and technology staff. Vocational education and professional training are emphasised in the reports from Poland (2020b), Portugal (2020b) and Slovenia (2020b), albeit concerns for education are lower in the latter country. Therefore, it can be said that these countries' plans reveal the same perspective on professionalizing workers by building knowledge and skills related to new technologies and green solutions but avoid presenting clear programmes and activities directed at other sectors of the population.

It must be stressed that the role of consumers is emphasised in all three national plans; somehow, the main perspective on society in climate change is that on consumers in the market as buyers of services or products. Campaigns targeted at people are generally aimed at raising public awareness of sustainability and development topics, at changing lifestyles and at containing climate change by changing habits. But the value-based part of sustainability is not visible in the analysed plans, and it is not clear how these changes will happen without the support of adult learning and education (formal and non-formal) activities directed at several social sectors. In fact, there are minor differences in the extent to which learning and education are presented in the analysed plans, with the Slovenian 
plan being most outspoken of the three when it comes to addressing education and learning, whereas the Polish plan has least to say about this issue.

[...] to draw up and carry out a comprehensive national promotion and literacy campaign on the importance and mode of transition to a climate-neutral society [in 2020], e.g.:

- themed ads on TV and web content,

- organisation of thematic events (kindergartens, schools, universities, local communities, non-governmental organisations, etc.),

- climate week ( $3^{\text {rd }}$ week of October). (Slovenia, 2020b, p.106)

In the Slovenian plan, the connection to formal education is highlighted at some stage; to some extent, we can also see this in case of Portugal, but in this plan, the relationship is much more fragmented. In Poland, some funds for ecological education are referred, but these are not seen as strategic priorities. Also, the narrative is slightly different, because the Polish focus is on mitigating the risks and negative effects of climate change by strengthening innovative and technological contributions based on vocational education and training/professional training and expert capacities.

Providing investment support for farms along with training and technology advisory services, taking into account issues concerning the adaptation of agricultural production to an increased climate risk and climate change prevention. (Poland, 2020b, pp. 73-74)

\section{Learners' roles and forms of learning}

The learners' roles in various adult learning and education activities mentioned in the plans vary significantly among the countries considered. The only two groups of learners that appear in all three plans are commuters and consumers (groups that should include most adults). The immediate aim of addressing commuters is the same in Portugal and Slovenia - to decrease the number of vehicles on the roads and promote public transportation and biking, while in Poland the focus is on the (potential) users of electric vehicles. The Slovenian NECP (Slovenia, 2020b) also mentions travelling (and not just commuting), planning to implement adult learning and education activities 'to reach the widest possible public and change travel habits' (p. 65). Regarding consumers, the immediate aim is the same in all three plans - to make them more aware of their position on the energy market. There are a few learners' groups throughout the NECPs that should 
include most (if not all) adults. Two such groups are local communities in Poland, targeted in order to become energy producers and to 'change their negative attitude towards investment projects' (Poland, 2020b, p. 101), and household members in Portugal and Slovenia, addressed in the Portuguese plan as (potential) energy producers and in the Slovenian plan in the context of transitioning to the use of more sustainable heating appliances. The Slovenian NECP also generally targets people that do not (yet) use clean energy or use more energy than needed, while the Polish NECP emphasises people from areas prone to natural disasters as a special adult learning and education target group.

Another quite broad category of learners in the Portuguese and Slovenian NECPs are the professionals that work in different areas with a high potential of contributing to energy efficiency (e.g. workers in the energy and transport sectors, sellers and installers of energy-efficient appliances, chimney sweepers, first responders, building managers). Different occupations seem to be the most specifically addressed, as medical workers and entrepreneurs are also mentioned as special adult learning and education target groups (in the Polish plan in particular), as well as farmers and civil servants (in the Polish and Slovenian plans). The Portuguese NECP (Portugal, 2020b, p. 53) similarly states that the 'public administration also plays an important role in leading the way toward decarbonisation' and even argues that the role of state departments is 'equally essential' as the role of research and innovation; and yet, the Portuguese plan does not specify any adult learning and education activities for public servants. In sum, generally, there seem to be two main categories of adult learning and education target groups to be addressed in line with the analysed NECPs: 1) the all-encompassing target groups and 2) the specific vocational target groups.

All three countries mention various forms of adult learning and education in their plans. The contribution to sustainable development through formal and non-formal education is present in all of them, as well as support for informal learning on relevant topics. In connection with the latter, all three NECPs refer to different information/media campaigns in order to reduce energy poverty, promote cleaner energy and encourage energy efficiency through the transformation of behaviours and attitudes. One way of achieving such a transformation, found in all analysed NECPs, is to raise awareness about the rights of the consumers on the energy market. Additionally, information campaigns in Poland aim to promote greener technologies and other relevant ways of increasing energy efficiency; in Portugal, to promote sustainable production and consumption (with a focus on certain industries), low-carbon economy and use of greener means of transportation; and in Slovenia, to 'improve overall energy and climate literacy' (Slovenia, 2020b, p. 215). Slovenia is also the only country to (already) have out- 
lined a media campaign featuring television and online advertisements, different thematic events in educational institutions and local communities, and an annual climate week.

Among more structured forms of education and learning, vocational education and training/professional training is the main one, although Portugal and Slovenia specify plans to introduce more environmental topics into schools (also in pre-school education) and universities. Training is even mentioned more times than education in all three NECPs, often in relation to certain target groups. Training is not always directed at tackling climate change, for instance in the Polish plan of planning special programmes to achieve '[a]n increase in the sale of technologies by Polish companies in international markets' (Poland, 2020b, p. 47). The Polish and the Portuguese plans additionally mention re-training (especially for workers from sectors heavily dependent on fossil fuels), whereas the Polish and Slovenian NECPs also plan to facilitate vocational education and training/professional training through counselling, mainly on the topic of sustainable forms of farming. For this reason, the Slovenian government plans to organise 'training[s] [for] agricultural advisers on the latest approaches in sustainable agriculture' (Slovenia, 2020b, p. 68). Besides that, all three countries are planning to establish digital (learning) platforms to make learning content on energy and climate widely accessible. Through them, Portuguese citizens will be able to compare different energy providers or get information about energyefficient building(s), Polish citizens will be able to access general information about climate change or learn about clean technologies, and Slovenian citizens will be able to see their current options of public transportation and co-travel or learn about sustainable business models.

\section{Discussion}

The compared NECPs show a similar understanding of (sustainable) development, which is a narrow one based on liberal theory (Escobar, 2005). This understanding is mostly focused on clean energy and new technologies to reach green transformation. From an educational perspective, the thematic scope is also narrowed to raise awareness among citizens, who are seen as potential consumers, of the benefits of the green energy available on the market without encouraging a deeper understanding of global and local interdependencies (Krause, 2010). Critical approaches to development (Escobar, 2005) or holistic and ethical perspectives on living on planet Earth (e.g. Dussel, 2015) are completely absent from the documents. Additionally, the policy process was initiated at the European level 
and then implemented on the national level, based on existing evidence of the role of the state, the market and civil society and local groups of citizens in consultation. The top-down approach is visible not only in the process of adapting the EU guidelines to the national contexts but also when considering the lack of understanding concerning the role local communities can play in the implementation process towards significant changes in energy consumption and lifestyles (Escobar, 2005, 2012; Krause, 2010). The strong role of the neoliberal market and innovative technologies in shaping the agenda changed the focus from local sustainability to worldwide green competition, where Western countries would like to retain their economic predominance. The perception of sustainable development is in fact the weakest point of the NECPs, as it influences further understanding and questions the possibility to reach meaningful changes in a long-term perspective. The missing role of (adult learning and) education is clear; the lack of consultation of civil society organisations working on sustainable development is also evident, as well as local communities referring to people's interests and wills when it comes to the future of humankind. Global interdependencies based on a neoliberal agenda hamper the ambitions of doing business and even fostering big business; and have a negative impact on shaping the plans. Therefore, the progress-oriented and aware citizen approach identified earlier in our typology (Escobar, 2005; Krause, 2010) is clearly predominant in the perception of sustainable development, with all the implications of this model.

The plans' emphasis on economic growth influences the understanding and role of adult learning and education by focusing mostly on training of adults to deliver innovative products on the market to reduce energy consumption and mitigate the negative impact of climate change. This leads to the progress-oriented and aware citizen approach (Escobar, 2005; Krause, 2010). The educational approach towards societies is concentrated only on awareness-raising aspects, which influence consumer behaviours and change habits towards a more sustainable environment, but still under the existing model of consumption. There is no deeper and critical knowledge and practice to reach significant changes in a longterm perspective; there is not even an attempt to work with people in general and local communities in particular on real alternatives opposed to the neoliberal market rules. The lack of a transformative approach in the role of adult learning and education seems to be the lost opportunity in the policy documents analysed here; the plans seem to stress mostly the tools to be used rather than the main goals related to the link between development and education.

The progress-oriented and aware citizen approach (Escobar, 2005; Krause, 2010 ) is, therefore, the dominant approach also when it comes to the identified adult learning and education target groups and forms of learning in the NECPs. 
Even though the specified target groups of learners essentially include adults in general (which should generate a broad need to implement diverse adult learning and education activities), the identified forms of adult learning and education still seem to be more or less superficial, with a minuscule extent focused on influencing the development of certain citizens' behaviours, rather than addressing the roots of crucial environmental and social problems. At the same time, vocational education and training/professional training appear as the main ways of addressing different target groups (or at least the most clearly outlined), as different occupations are emphasised, whereas (non-vocational) adult learning and education is directed only at broad, anonymous social and educational sectors. Consequently, vocational education and training/professional training is the preferred adult learning and education form in all three countries, which is also indicative of the NECPs' instrumental understanding of adult learning and education. The aim of addressing different target groups, as planned in the NECPs, is to make learners more energy-efficient and to promote the transition to the use of clean(er) energy (or make people do something that directly contributes to that) in the frame of the current economic, political and environmental order. Therefore, the goal is not to radically change the economic system that brought us to the current social and environmental conditions, as, for example, proponents of degrowth (Kallis et al., 2015; Latouche, 2012), buen vivir [well living] and the pluriverse (Escobar, 2012) approaches would argue, or even as proposed in the more ethically based perspectives of development (Dussel, 2015), but to adapt citizens in a way that allows, or even accelerates, further economic development, while not damaging the environment (too much) in any irreversible way. In fact, in all three NECPs, even in regard to more structured adult learning and education forms, citizens are mostly perceived as entities that need to be informed in order to behave properly and develop the right attitudes. It is through such positioning that the top-down approach to adult learning and education is most clearly exposed.

Although the Polish, Portuguese and Slovenian plans refer to utilizing different adult learning and education activities to transform the behaviours and attitudes of their citizens regarding energy efficiency and clean energy, they all give great importance to some rather superficial forms, such as media campaigns and informing through digital platforms. Reaching as many people as possible on the topics of sustainable development is certainly important, but it should not come at the cost of diminishing the critical role of adult learning and education or neglecting the active role of the learners in making substantial changes to build alternative forms of thinking, living and producing. 


\section{Conclusion}

The analysis of the NECPs has revealed the hegemonic and narrow understanding of sustainable development, following the liberal theory (Escobar, 2005) and the awareness raising approach in (adult learning and) education (Krause, 2010); following this line of reasoning, the absence of critical and holistic approaches of adult learning and education were noticed. The top-down approach presented in the policy documents follows the modernisation paradigm in development that still supports market-oriented and Eurocentric perspectives, without deeper reflection on regional contexts and local communities' ownership. The documents from Poland, Portugal, and Slovenia support a neoliberal development agenda, where economic growth is considered the core value. Nevertheless, there are questions that need to be raised in order to examine the lost opportunity of implementation and to summon the opportunity which the next NECPs in 2030 can represent. The questions are: What are the roles of adult learning and education in postponing 'the last whimper' on this planet? In order to promote the influential role of adult learning and education for sustainability, what kind of ontological, epistemological, and axiological foundation should be suggested for the new understanding of development in future EU (initiated) policies, namely the 2030 NECPs?

\section{References}

Andreotti, V. (2014). Soft versus critical global citizenship education. In S. McCloskey (Ed.), Development education in policy and practice, 21-31. London: Palgrave Macmillan.

Bassot, E., \& Hiller, W. (2019). The Juncker Commission's ten priorities: An end-of-term assessment. Brussels: European Union.

Bowen, G. A. (2003). Social funds as a strategy for poverty reduction in Jamaica: An exploratory study (Doctoral dissertation). Florida International University, Miami.

Bowen, G. A. (2009). Document analysis as a qualitative research method. Qualitative Research Journal, 9(2), 27-40. https://doi.org/10.3316/QRJ0902027

Brundtland Commission. (1987). Our common future. Retrieved from https://sustainabledevelopment.un.org/content/documents/5987our-common-future.pdf

Denzin, N. K. (2018). The qualitative manifesto: A call to arms. London: Routledge.

Dussel, E. (2015). 14 tesis de ética. Buenos Aires: Docencia.

EgetenMeyer, R. (2012, November). Informal learning of managers in a multinational company in Germany, Great Britain and Spain: An intercultural comparison. In M. Bron Jr., \& J. Reischmann (Eds.), Proceedings of ISCAE Conference Las Vegas (pp. 77-89). Las Vegas: ISCAE. 
Escobar, A. (2005). El 'postdesarrollo' como concepto y práctica social. In D. Mato (Ed.), Politicas de economía, ambiente y sociedad en tiempos de globalización (pp. 17-31). Caracas: Facultad de Ciencias Económicas y Sociales, Universidad Central de Venezuela.

Escobar, A. (2012). Más allá del desarrollo: Postdesarrollo y transiciones hacia el pluriverso. Revista de Antropología Social, 21, 23-62.

European Commission (2019b). The European green deal. Retrieved from https:// ec.europa.eu/info/sites/info/files/european-green-deal-communication_en.pdf.

European Commission (2014). A policy framework for climate and energy in the period from 2020 to 2030. Retrieved from https://eur-lex.europa.eu/legal-content/EN/ TXT/?uri=CELEX:52014DC0015.

European Commission (2018). 2030 climate \& energy framework. Retrieved from https://ec.europa.eu/clima/policies/strategies/2030_en\#tab-0-0.

European Commission (2019a). National energy and climate plans (NECPs). Retrieved from https://ec.europa.eu/energy/topics/energy-strategy/national-energy-climateplans_en?redir $=1$.

European Commission (2020). Energy union. Retrieved from https://ec.europa.eu/energy/topics/energy-strategy/energy-union_en\#regulation-on-the-governance-ofthe-energy-union-and-climate-action.

EUROPEAN UNION (2015). A framework strategy for a resilient energy union with a forwardlooking climate change policy. Retrieved from https://eur-lex.europa.eu/legal-content/EN/TXT/?uri=COM:2015:80:FIN.

European Union (2018a). Regulation (EU) 2018/1999 of the European Parliament and of the Council of 11 December 2018 on the governance of the energy union and climate action. Brussels: Official Journal of the European Union.

European Union (2018b). The new European consensus on development: 'Our world, our dignity, our future'. Luxembourg: Publications Office of the European Union.

Freire, P. (1968). Educação e conscientização: Extencionismo rural. Cuernavaca: CIDOC/Cuaderno, no. 25.

Giroux, H. A. (2001). Public spaces, private lives: Beyond the culture of cynicism. London: Rowman \& Littlefield.

Hart, G. (2001). Development critiques in the 1990s: Culs de sac and promising paths. Progress in Human Geography, 24(4), 649-658. https://doi. org/10.1191/030913201682689002

Intergovernmental Panel on Climate Change (2019). Global warming of $1.5{ }^{\circ} \mathrm{C}$. Retrieved from https://www.ipcc.ch/sr15.

Kallis, G., Demaria, F., \& D’Alisa, G. (2015). Introduction: Degrowth. In G. D'Alisa, F. Demaria, \& G. Kallis (Eds.), Degrowth: A vocabulary for a new era (pp. 29-46). New York/London: Routledge.

KaY, C. (1998). Relevance of structuralist and dependency theories in the neoliberal period: A Latin American perspective (Working paper series, n. ${ }^{o}$ 281). Hague: Institute of Political Studies. 
Krause, J. (2010). The European development education monitoring report: Development education watch. Brussels: DEEEP.

Latouche, S. (2012). Pequeno tratado do decrescimento sereno. Lisboa: Ediçóes 70.

Manzo, K. (1991). Modernist discourse and the crisis of development theory. Studies in Comparative International Development, 26(2), 3-36. Retrieved from https://doi. org/10.1007/BF02717866

Mason, M. (2007). Comparing cultures. In M. Bray, B. Adamson, \& M. Mason (Eds.), Comparative education research: Approaches and methods (pp. 165-196). Honk Kong: Springer.

Ministry of state Assests of the Republic of Poland (2020a). Krajowy Plan na rzecz energii i klimatu na lata 2021-2030. Retrieved from https://www.gov.pl/web/klimat/krajowy-plan-na-rzecz-energii-i-klimatu.

Ministry of state Assests of the Republic of Poland (2020b). Polish national energy and climate plan. Retrieved from https://ec.europa.eu/energy/sites/ener/files/ documents/pl_final_necp_part_1_3_en.pdf.

SACHs, W. (1999). Environment. In W. Sachs (Ed.), The development dictionary: A guide to knowledge as power (pp. 24-37). London: Zed Books.

SAID, E. (1979). Orientalism. New York: Random House.

Schmidt, L., \& Guerra, J. (2013). Do ambiente ao desenvolvimento sustentável: contextos protagonistas da educação ambiental em Portugal. Revista Lusófona de Educação, 25, 193-211.

Selby, D., \& Kagawa, F. (2014). Striking a Faustian bargain? Development education, education for sustainable development and the economic growth agenda. In S. McCloskey (Ed.), Development education in policy and practice (pp. 143-157). London: Palgrave Macmillan.

Tandon, Y. (2008). Ending aid dependence. Cape Town, Dakar, Nairobi and Oxford: Fahamu - Networks for Social Justice.

The Government of Portugal (2020a). Plano Nacional Energia e Clima 2021-2030 (PNEC 2030). Retrieved from https://ec.europa.eu/energy/sites/ener/files/documents/pt_final_necp_main_pt.pdf.

The Government of Portugal (2020b). Portuguese national energy and climate plan. Retrieved from https://ec.europa.eu/energy/sites/ener/files/documents/pt_final_ necp_main_en.pdf.

The Government of the Republic of Slovenia (2020a). Celoviti nacionalni energetski in podnebni načrt Republike Slovenije. Retrieved from https://ec.europa.eu/energy/ sites/ener/files/si_final_necp_main_sl.pdf.

The Government of the Republic of Slovenia (2020b). Slovenian national energy and climate plan. Retrieved from https://ec.europa.eu/energy/sites/ener/files/documents/si_final_necp_main_en.pdf.

United Nations (2015). Transforming our world: The 2030 agenda for sustainable development. Retrieved from https://sustainabledevelopment.un.org/post2015/transformingourworld. 
Tadej Košmerl ${ }^{8}$

Univerzitet u Ljubljani, Slovenija

Marta Gontarska ${ }^{9}$

Univerzitet Donje Šlezije u Vroclavu, Poljska

Yeonjoo $\mathrm{Kim}^{10}$

Univerzitet Britanske Kolumbije, Kanada

Paula Guimarães ${ }^{11}$

Univerzitet u Lisabonu, Portugalija

\section{Kako odložiti „jecaj“ pred kraj: učenje i obrazovanje odraslih s ciljem održivog razvoja u nacionalnim energetskim i klimatskim planovima u Poljskoj, Portugaliji i Sloveniji}

Ovako svetu dođe kraj. Ne s tutnjem već s jecajem. (T. S. Eliot, Šuplji ljudi, 1925)

Apstrakt: Ovaj rad upoređuje diskurse nacionalnih energetskih i klimatskih planova (NECP) Poljske, Portugalije i Slovenije u pogledu uloga učenja i obrazovanja odraslih s ciljem održivog razvoja. Nacionalni energetski i klimatski planovi su analizirani kroz teoretski predlog zasnovan na Krauseovim (2010) i Escobarovim (2005) doprinosima, pri čemu su uspostavljena tri pristupa razvoju, učenju i obrazovanju odraslih: a) osvešćeni građanski pristup koji je orijentisan na napredak; b) globalni, kritički i transformativni pristup i c) aktivni globalni i lokalni participativni pristup. Glavni zaključci ističu osve-

8 Tadej Košmerl, student doktorskih studija i saradnik u nastavi, Katedra za obrazovne nauke, Fakultet društvenih nauka, Univerzitet u Ljubljani (tadej.kosmerl@ff.uni-lj.si).

9 Marta Gontarska, student doktorskih studija, Fakultet strukovnih studija, Univerzitet Donje Šlezije u Vroclavu, Poljska (marta.gontarska@student.dsw.edu.pl).

${ }^{10}$ Yeonjoo Kim, student doktorskih studija, Katedra za obrazovne nauke, Fakultet obrazovanja, Univerzitet Britanske Kolumbije, Vankuver, Kanada (yeonjook@mail.ubc.ca).

${ }^{11}$ Dr Paula Guimarães, docentkinja, Institut za obrazovanje, Univerzitet u Lisabonu, Portugalija (pguimaraes@ ie.ulisboa.pt). 
šćen građanski pristup koji je orijentisan na napredak u NECP planovima iniciranim od EU. Uz to, pristup odozgo nadole je očigledan u dokumentima o politikama, kao i u usklađivanju sa liberalnom teorijom razvoja bez značajnijeg odraza na lokalne kontekste, pri čemu se zapaža marginalna uloga učenja i obrazovanja odraslih.

Ključne reči: obrazovanje s ciljem održivog razvoja, učenje i obrazovanje odraslih, klimatske promene, Evropska unija 